\title{
Uji Aktivitas Antibakteri Ekstrak Etanol Daun Kacapiring (Gardenia augusta Merr.) dan Fraksinya Terhadap Salmonella typhi
}

\author{
Mohammad Thahir Kherid ${ }^{1}$, Dewi Dianasari ${ }^{1}$, Nuri $^{1}$ \\ ${ }^{1}$ Fakultas Farmasi, Universitas Jember, Jember, Indonesia
}

Juni 2020

Kata kunci :

Infeksi, Tifoid,

Salmonella typhi,

Antibakteri,

Gardenia augusta

\begin{abstract}
INFO ARTIKEL
Sejarah artikel:

Penerimaan

naskah: 15 Januari

2020

Penerimaan

naskah revisi: 2

April 2020

Disetujui untuk

dipublikasikan: 9

\section{A B S T R A K}

Tifoid merupakan penyakit infeksi bakteri Salmonella typhi. Pengobatan konvensional tifoid dilakukan dengan penggunaan antibiotik. Irasionalitas penggunaan antibiotik terhadap $S$. typhi dilaporkan memicu resistensi bakteri, sehingga dibutuhkan alternatif agen antibakteri terhadap tifoid. Keanekaragaman tanaman obat Indonesia masih menjanjikan sebagai sumber antibakteri yang potensial, salah satunya kacapiring (Gardenia augusta Merr.). Penelitian ini bertujuan untuk mengetahui aktivitas antibakteri ekstrak etanol daun kacapiring dan fraksinya terhadap S. typhi. Fraksinasi dilakukan secara bertingkat dengan metode partisi cair-cair untuk mendapatkan fraksi n-heksana, etil asetat, dan etanol-air. Uji antibakteri dilakukan dengan metode difusi cakram untuk menentukan nilai diameter zona hambat pada konsentrasi uji 20\%, 25\%, 30\%, dan 40\%. Aktivitas antibakteri terbaik dicapai oleh fraksi residu konsentrasi 30\% dan 40\% dengan diameter zona hambat masing-masing sebesar 7.564 $\pm 0,081 \mathrm{~mm}$ dan 8.529 $\pm 0,081$ $\mathrm{mm}$. Kacapiring mememiliki aktivitas antibakteri moderat terhadap pertumbuhan S.typhi.
\end{abstract}

\section{Antibacterial Activity Test of Ethanol Extracts of Kacapiring Leaf (Gardenia augusta Merr.) and The Fraction of Salmonella typhi}

\section{Keywords:}

Infection, Typhoid

,Salmonella typhi,

Antibacterial,

Gardenia augusta

\begin{abstract}
A B S T R A C T
Typhoid is a bacterial infection disease of Salmonella typhi. Conventionally, typhoid treatment is carried out with antibiotics. The irrationality of antibiotics against $S$. typhi is reported to trigger bacterial resistance, thus requiring an alternative antibacterial agent against typhoid. The diversity of Indonesian medicinal plants is still promising as a potential source of antibacterial agent, including kacapiring (Gardenia augusta Merr.). This study was aimed to determine antibacterial activity of ethanol extract of kacapiring leaves and its fractions against $S$. typhi. Subsequent fractionation was carried out using liquid-liquid partition method to obtain n-hexane, ethyl acetate, and etanol-water fractions. Antibacterial test was carried out using disk diffusion method to determine the diameter of inhibitory zone at concentrations of $20 \%, 25 \%, 30 \%$, and $40 \%$. The best antibacterial activity was revealed by residue fraction of $30 \%$ and $40 \%$ with inhibition zone diameter of 7,564 $\pm 0.081 \mathrm{~mm}$ and 8,529 $\pm 0.081 \mathrm{~mm}$, respectively. Kacapiring have moderate antibacterial activity against S.typhi.
\end{abstract}

\section{Pendahuluan}

Infeksi merupakan salah satu penyebab kematian (mortality) di dunia dengan jumlah kematian sebanyak 15 juta pada tahun 2010 dan dua pertiga dari data kematian ini disebabkan oleh bakteri dan virus [1]. Infeksi merupakan suatu gangguan penyakit yang disebabkan oleh adanya bakteri, parasit, virus, mikroba dan patogen dari luar yang menginvasi ke dalam tubuh dan menyebabkan terjadinya infeksi [2].
Infeksi perlu mendapat perhatian khusus dalam upaya penanganan dan pencegahan terutama pada penyakit tifoid. World Health Organization (WHO) secara global memperkirakan penyakit tipus mencapai 11-20 juta kasus setiap tahun, dengan menghasilkan sekitar 128.000161.000 kematian setiap tahun [3]. Indonesia termasuk salah satu negara yang sering dijumpai kasus infeksi tifoid seperti halnya di Jakarta terdapat 182 kasus setiap hari. Sebanyak $64 \%$ infeksi demam tifoid terjadi pada penderita berusia 3-19 tahun [4]. Kondisi ini menunjukkan infeksi 
tifoid masih memiliki angka kesakitan dan kematian cukup tinggi baik secara nasional maupun internasional.

Infeksi tifoid disebabkan oleh bakteri Salmonella typhi (S. typhi) melalui makanan atau minuman yang masuk ke dalam tubuh [5]. Antibakteri merupakan suatu agen atau zat yang berfungsi untuk menghambat proses pertumbuhan dan poliferasi bakteri serta dapat membunuh suatu sel bakteri tertentu [6].

Saat ini pengobatan antibakteri umumnya dilakukan dengan pemberian obat-obatan antibiotik seperti amoksisilin, ampisilin, dan kloramfenikol dan antibiotik lainnya yang digunakan sebagai terapi antibakteri. Penggunaan antibiotik yang tidak rasional menyebabkan banyak terjadinya kasus resistensi bakteri [7], dan timbulnya efek samping dan reaksi yang merugikan lainnya [8]. Oleh karena itu, untuk mengurangi resistensi dan efek samping yang merugikan, maka diperlukan alternatif lain melalui penemuan inovasi antibakteri baru yang diharapkan lebih efektif dalam pengobatan dan lebih aman dalam penggunaan.

Tumbuhan memiliki fungsi sebagai agen antibakteri karena mengandung senyawa metabolit sekunder [9]. Beberapa penelitian telah membuktikan bahwa senyawa aktif tumbuhan memiliki fungsi sebagai agen antibakteri, salah satunya pada tumbuhan dari genus Gardenia. Ekstrak metanol daun G. coronaria $500 \mu \mathrm{g} / \mathrm{mL}$ memiliki aktivitas terhadap Streptococcus agalactiae dan Bacillus cereus masing-masing $16 \mathrm{~mm}$ [10]. Ekstrak metanol kulit batang G. aqualla $50 \mathrm{mg} / \mathrm{mL}$ aktivitas oenghambatan $35 \mathrm{~mm}$ terhadap $S$. typhi [11]. Ekstrak pigmen kuning dari buah $G$. jasminoides $30 \mu \mathrm{g} / \mathrm{mL}$ memiliki aktivitas antibakteri terhadap spesies Proteus dan bakteri Bacillus subtilis dengan diameter zona hambat masing-masing 19,3 mm dan 17,4 mm [12]. Ekstrak etanol daun G. gummifera $1500 \mu \mathrm{g} / \mathrm{mL}$ memilki aktivitas antibakteri terhadap bakteri $S$. typhi dengan diameter zona hambat $12,33 \mathrm{~mm}$ [13]. Berdasarkan beberapa hasil penelitian di atas menunjukkan bahwa tumbuhan dari genus Gardenia memiliki potensi sebagai agen antibakter. Hingga saat ini belum ditemukan data penelitian terkait uji aktivitas antibakteri dari Gardenia augusta baik pada ekstrak maupun fraksinya terhadap S. typhi. Oleh karena itu, pada penelitian ini akan dilakukan uji aktivitas antibakteri ekstrak etanol daun kacapiring G. augusta dan fraksinya terhadap S. typhi.

Penelitian ini diawali dengan proses ekstraksi kemudian dilakukan uji antibakteri untuk mengetahui aktivitasnya dan dilanjutkan fraksinasi dan pengujian aktivitas antibakteri pada setiap fraksi untuk mengetahui fraksi mana yang diduga memiliki aktivitas antibakteri.

Pengujian aktivitas antibakteri dilakukan dengan menggunakan metode difusi cakram. Aktivitas antibakteri dapat diamati berdasarkan diameter zona hambat terhadap pertumbuhan $S$. typhi. Fraksi yang digunakan adalah fraksi n-heksana, fraksi etil asetat, dan fraksi etanol-air. Hasil dari penelitian ini diharapkan mampu memberikan informasi ilmiah mengenai potensi daun kacapiring sebagai agen antibakteri.

\section{Metode}

\subsection{Alat dan Bahan}

Alat-alat yang digunakan adalah Timbangan analitik. (Sartonius CP224S), oven (Memmert), Rotary evaporator (Heidolph), Mikropipet 10-1-100 $\mu 1$ (Socorex), Mikropipet 100-1000 $\mu 1$ (Eppendorf), Hotplate, Microtip, microtube, vortex (Labnet), Aluminium foil (Klin-pak), Autoklaf (ALP), Laminar Air Flow (Thermo SCIENTIFIC 13000 SERIES A2) dan Inkubator (Clifton). Bahan-bahan yang digunakan dalam penelitian ini meliputi: daun Gardenia augusta yang diambil secara acak di Kecamatan Umbulsari Kabupaten Jember, Salmonella thypi yang diperoleh dari Laboratorium Mikrobiologi Fakultas Kedokteran Universitas Brawijaya. Natrium Agar (NA) dan Mueller Hinton Agar (MHA), etanol 96\%, n-heksana, etil asetat $\mathrm{NaCl}$ fisiologis $0.9 \%$, DMSO $10 \%$ (dimetil sulfoksida), akuades steril, Cakram blank disk dan cakram kloramfenikol $30 \mu \mathrm{g}$. Penelitian ini dilakukan di Laboratorium Mikrobiologi dan Bioteknologi Bagian Biologi Farmasi Fakultas Farmasi Universitas Jember pada bulan April 2019 sampai bulan Agustus 2019.

\subsection{Ekstraksi}

Ekstrak etanol daun kacapiring dibuat dengan cara menimbang simplisia serbuk 200 gram kemudian dimasukkan ke maserator dan ditambahkan etanol $96 \%$ $2000 \mathrm{~mL}$ (1:10) untuk dilakukan ekstraksi maserasi dan dilakukan pengadukan setiap 24 jam. Maserat kemudian disaring menggunakan corong buchner untuk memisahkan residu. Filtrat yang diperoleh dipekatkan menggunakan rotary evaporator untuk memisahkan senyawa kimia yang melekat pada pelarut. Residu yang tersisa selanjutnya dilakukan maserasi kembali menggunakan pelarut yang tersisa hasil pemekatan. Hasil dari maserasi berulang selanjutnya dilakukan penyaringan, penguapan dan pengeringan hingga terbentuk esktrak kental. Ekstrak kental kemudian ditimbang dan dihitung rendemennya.

\subsection{Fraksinasi}

Ekstrak kental yang diperoleh selanjutnya dibuat fraksi menggunakan etanol-air, n-heksana dan etil asetat melalui metode partisi cair-cair. Sebanyak 4,8 gram ekstrak kental dilarutkan dalam $8 \mathrm{~mL}$ etanol dan $72 \mathrm{~mL}$ akuades. Larutan selanjutnya dimasukkan ke dalam corong pisah dan dipartisi dengan $80 \mathrm{~mL}$ n-heksana kemudian dikocok dan didiamkan hingga terbentuk dua fase larutan yang terpisah. Fraksi n-heksana kemudian ditampung dan diuapkan hingga terbentuk fraksi kental. Selanjutnya dengan proses yang sama fraksi etanol-air dipartisi kembali menggunakan etil asetat. Fraksi etil asetat dan fraksi etanol-air kemudian ditampung dan diuapkan hingga masing-masing terbentuk fraksi kental. Hasil semua fraksi selanjutnya ditimbang dan dihitung rendemennya [14]. 


\subsection{Pembuatan Media Bakteri}

\subsubsection{Media Na}

Media Na digunakan sebagai media biakan atau peremajaan bakteri. Media biakan bakteri dibuat dengan cara serbuk ditimbang sebanyak $0,69 \mathrm{~g}$ serbuk $\mathrm{Na}$ kemudian dilarutkan dengan akuades $30 \mathrm{~mL}$ dalam erlenmeyer $50 \mathrm{~mL}$ dan dipanaskan hingga homogen dan larut sempurna. Selanjutnya media $\mathrm{Na} 5$ $\mathrm{mL}$ dituang ke dalam 5 tabung reaksi dan disterilisasi menggunakan autoklaf pada suhu $121^{\circ} \mathrm{C}$ dan selama \pm 15 menit. Setelah itu media $\mathrm{Na}$ steril dimasukkan ke dalam lemari pendingin dengan posisi miring $45^{\circ} \mathrm{C}$ hingga terbentuk media agar miring.

Media Na yang telah dibuat selanjutnya dilakukan Peremajan bakteri Proses peremajaan bakteri dilakukan dengan cara mengambil koloni bakteri murni kemudian digoreskan pada media NA menggunakan jarum ose dalam tabung reaksi. Proses tersebut dilakukan secara aseptis dibawah LAF dan diinkubasi pada suhu $37{ }^{\circ} \mathrm{C}$ selama 18 24 jam.

\subsubsection{Media MHA}

Media MHA digunakan sebagai media pengujian bakteri. Media dibuat dengan cara ditimbang sebanyak 20,9 g kemudian dilarutkan dengan aquadest $550 \mathrm{~mL}$ dan dipanaskan hingga homogen dan larut sempurna. Media MHA sebanyak $15 \mathrm{ml}$ selanjutnya dituang ke dalam 36 tabung reaksi dan disterilisasi dengan autoklaf pada suhu $121^{\circ} \mathrm{C}$ selama \pm 15 menit. Kemudian media MHA steril dimasukkan ke dalam lemari pendingin hingga terbentuk media agar padat.

\subsection{Pembuatan Larutan Uji \& Kelompok Kontrol}

larutan uji ekstrak etanol daun kacapiring dan fraksinya dibuat dengan empat seri konsentrasi, yaitu 20\%, 25\%, 30\%, dan 40\%. Pembuatan larutan uji ekstrak dilakukan dengan cara membuat larutan induk yaitu menimbang ekstrak 0,4 g kemudian dilarutkan dengan 1 $\mathrm{mL}$ DMSO $10 \%$ untuk mendapatkan konsentrasi $40 \%$. Larutan uji $40 \%$ selanjutnya diencerkan hingga mendapatkan konsentrasi 30\%, 25\% dan 20\%. Pembuatan larutan uji pada fraksi menggunakan konsentrasi yang sama yaitu 20\%, 25\%, 30\%, dan 40\%. Pembuatan larutan uji pada fraksi dilakukan dengan proses yang sama dengan pembuatan larutan uji ekstrak. Kontrol negatif yang digunakan adalah DMSO $10 \%$ dibuat dengan cara dimasukkan $1 \mathrm{ml}$ DMSO 100\% kemudian ditambah akuades $9 \mathrm{ml}$ dan divorteks hingga homogen. Kontrol positif yang digunakan adalah cakram Kloramfenikol 30 $\mu \mathrm{g}$.

\subsection{Pembuatan Suspensi S. typhi}

Suspensi bakteri dibuat dengan cara memasukkan sebanyak $10 \mathrm{~mL}$ larutan $\mathrm{NaCl} 0,9 \%$ ke dalam tabung reaksi, kemudian hasil biakan bakteri yang telah dibuat pada media $\mathrm{Na}$ diinokulasi ke dalam tabung reaksi yang telah terisi larutan $\mathrm{NaCl} 0,9 \%$ secara aseptis dan divorteks hingga suspensi homogen. Suspensi bakteri selanjutnya diukur absorbansi menggunakan speoktrofotometri hingga setara dengan Mc Farland 0,5 yaitu antara 0,08-0,13 (3 X $\left.10^{8} \mathrm{CFU} / \mathrm{mL}\right)$. Jika suspensi bakteri telah memenuhi rentang absorbansi esuai standar Mc Farland maka suspensi bakteri siap digunakan untuk pengujian antibakteri.

\subsection{Uji Antibakteri}

Uji antibakteri dilakukan untuk mengetahui potensi dari senyawa yang terkandung dalam ekstrak etanol daun kaca piring dan fraksi. Proses pengujian antibakteri pada ekstrak dilakukan dengan cara larutan uji konsentrasi $20 \%$, $25 \%, 30 \%$, dan $40 \%$ dan kontrol negatif DMSO $10 \%$ sebanyak $20 \mu \mathrm{L}$ diteteskan ke dalam cakram steril yang tersedia dan didiamkan selama 18-24 jam. Suspensi bakteri yang telah dibuat sebelumnya dituang $50 \mu \mathrm{L}$ ke dalam cawan petri yang telah terisi media padat MHA dan diratakan menggunakan cotton bud.

Larutan uji ekstrak, kontrol negatif DMSO 10\%, dan kontrol positif cakram kloramfenikol $30 \mu \mathrm{g}$ selanjutnya diletakkan ke dalam petri yang telah terisi bakteri uji. Kemudian diinkubasi pada suhu $37{ }^{\circ} \mathrm{C}$ selama 18 jam. Pengujian antibakteri pada fraksi n-heksana, fraksi etil asetat, dan fraksi etanol-air dilakukan dengan proses dan kondisi yang sama seperti pengujian aktivitas antibakteri pada ekstrak. Aktivitas antibakeri dapat diamati berdasarkan pengukuran diameter zona hambatnya menggunakan jangka sorong.

Hasil dari uji aktivitas antibakteri selanjutnya dianalisis secara statistik menggunakan SPSS dengan melakukan uji normalitas dan homogenitas serta uji Kruskal-wallis dan uji Mann-whitney dengan tingkat kepercayaan $95 \%(\alpha=0,05)$.

\section{Hasil dan Diskusi}

Ekstraksi dan fraksinasi merupakan bagian dari tahap awal pada penelitian ini. Hasil ekstrak yang didapatkan sebesar 20,05\% sementara pada fraksi heksana, fraksi etil asetat dan fraksi etanol-air berturut-turut adalah $17,409 \%$; 6,184\%; dan $65,535 \%$.

Hasil uji aktivitas antibakteri dapat menunjukkan bahwa dari semua sampel percobaan yang memiliki aktivitas antibakteri adalah pada sampel fraksi etanol air pada konsentrasi $30 \%$ dan $40 \%$. Hasil pengujian aktivitas antibakteri ekstrak etanol daun kacapiring dan fraksinya terhadap $S$. typhi dapat ditunjukkan pada gambar 1 dan Tabel 1

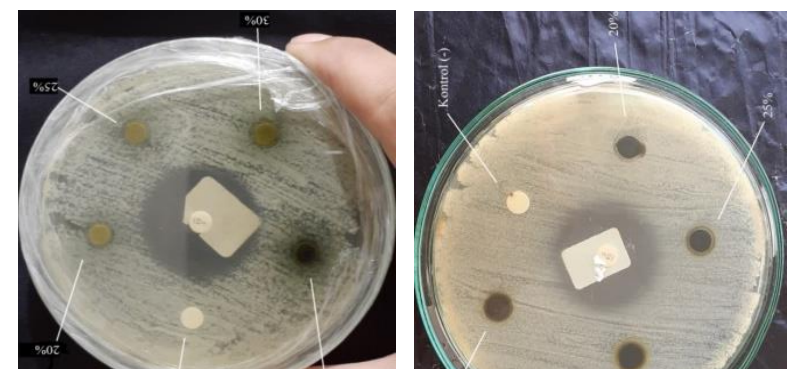




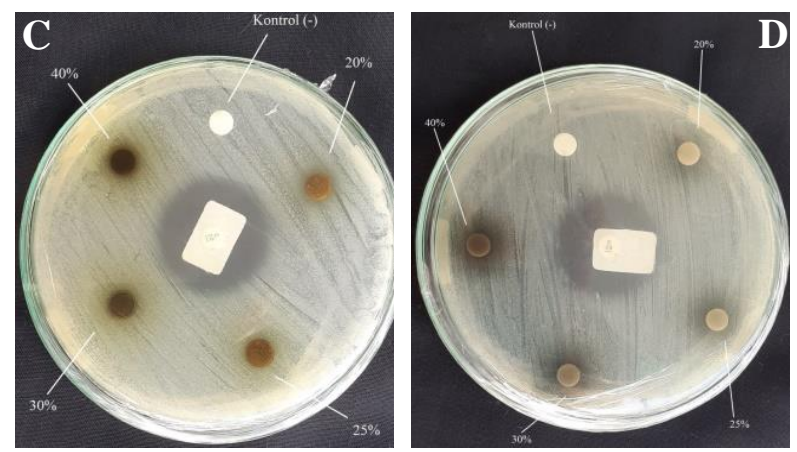

Gambar 1. Hasil uji aktivitas antibakteri daun kacapiring (G. augusta) metode difusi cakram A: ekstrak etanol; B: fraksi heksana; C: fraksi etil asetat; D: fraksi air-etanol. konsentrasi $20 \%$, 25\%, 30\%, dan 40\% terhadap S. typhi. kontrol positif kloramfenikol $30 \mu \mathrm{g}$, dan kontrol negatif DMSO 10\%.

\begin{tabular}{|c|c|c|c|}
\hline No & Kelompok uji & Konsentrasi & $\begin{array}{l}\text { Diameter hambat } \\
(\mathrm{mm} \pm \mathrm{SD})\end{array}$ \\
\hline \multirow{5}{*}{1} & \multirow{4}{*}{ Ekstrak } & $20 \%$ & $0,000^{\mathrm{a}}$ \\
\hline & & $25 \%$ & $0,000^{\mathrm{a}}$ \\
\hline & & $30 \%$ & $0,000^{\mathrm{a}}$ \\
\hline & & $40 \%$ & $0,000^{\mathrm{a}}$ \\
\hline & $\begin{array}{l}\mathrm{K}(+) \text { ekstrak } \\
\mathrm{K}(-) \text { ekstrak }\end{array}$ & $30 \mu \mathrm{g}$ & $\begin{array}{c}30,12 \pm 0,097^{\mathrm{b}} \\
0,000^{\mathrm{a}}\end{array}$ \\
\hline \multirow{5}{*}{2} & \multirow{4}{*}{$\begin{array}{l}\text { Fraksi n- } \\
\text { heksana }\end{array}$} & $20 \%$ & $0,000^{\mathrm{a}}$ \\
\hline & & $25 \%$ & $0,000^{\mathrm{a}}$ \\
\hline & & $30 \%$ & $0,000^{\text {a }}$ \\
\hline & & $40 \%$ & $0,000^{\mathrm{a}}$ \\
\hline & $\begin{array}{l}\mathrm{K}(+) \text { heksana } \\
\mathrm{K}(-) \text { heksana }\end{array}$ & $30 \mu \mathrm{g}$ & $\begin{array}{c}29,58 \pm 0,089^{\mathrm{b}} \\
0,000^{\mathrm{a}}\end{array}$ \\
\hline \multirow{5}{*}{3} & \multirow{4}{*}{ Fraksi etil asetat } & $20 \%$ & $0,000^{\mathrm{a}}$ \\
\hline & & $25 \%$ & $0,000^{\mathrm{a}}$ \\
\hline & & $30 \%$ & $0,000^{\mathrm{a}}$ \\
\hline & & $40 \%$ & $0,000^{\mathrm{a}}$ \\
\hline & $\begin{array}{l}\mathrm{K}(+) \mathrm{EA} \\
\mathrm{K}(-) \mathrm{EA}\end{array}$ & $30 \mu \mathrm{g}$ & $\begin{array}{c}29,3 \pm 0,086^{\mathbf{b}} \\
0,000^{\mathrm{a}}\end{array}$ \\
\hline \multirow{5}{*}{4} & \multirow{4}{*}{ Fraksi etanol-air } & $20 \%$ & $0,000^{\mathrm{a}}$ \\
\hline & & $25 \%$ & $0,000^{\mathrm{a}}$ \\
\hline & & $30 \%$ & $7.57 \pm 0,081^{\mathbf{b}, 1}$ \\
\hline & & $40 \%$ & $8.53 \pm 0,081^{\mathbf{b}, 1}$ \\
\hline & $\begin{array}{l}\mathrm{K}(+) \mathrm{EtOH} \\
\mathrm{K}(-) \mathrm{EtOH}\end{array}$ & $30 \mu \mathrm{g}$ & $\begin{array}{c}29,2 \pm 0,058^{\mathbf{b}, 1} \\
0,000^{\mathrm{a}}\end{array}$ \\
\hline
\end{tabular}

Tabel 1. Hasil pengukuran diameter zona hambat sampel ekstrak etanol daun kacapiring dan fraksinya $20 \%, 25 \%, 30 \%, 40 \%$ terhadap S.typhi

Notasi huruf a yang sama menunjukkan tidak ada perbedaan pada kelompok yang sama maupun yang beda

Notasi huruf b menunjukkan ada perbedaan terhadap jenis kelompok yang sama Notasi angka 1 menunjukkan ada perbedaan terhadap jenis kelompok yang sama maupun yang berbeda

Notasi b,1 yang sama menunjukkan tidak ada perbedaan pada jenis ekstrak/fraksi yang sama

Ekstraksi serbuk simplisia daun kacapiring dilakukan dengan menggunakan metode maserasi.
Metode maserasi dipilih karena dianggap lebih mudah dan sederhana, tidak membutuhkan proses pemanasan, dan aman untuk zat aktif yang terdegradasi akibat pemanasan. Penggunaan etanol didasari oleh kemampuannya untuk menyari sebagian besar metabolit sekunder yang terkandung dalam serbuk simplisia [14]. Pada fraksinasi digunakan metode partisi cair-cair. Metode ini dipilih karena relatif lebih mudah dan sederhana, dan tidak membutuhkan teknik pengerjaan khusus [15].

Berdasarkan hasil rendemen yang didapat menunjukkan bahwa fraksi etanol-air menghasilkan rendemen tertinggi diikuti fraksi heksana dan fraksi etil asetat dengan jumlah rendemen terendah. Fraksi etanol-air termasuk fraksi polar dimana pada fraksi ini dapat diduga mengandung senyawa yang terdiri dari flavonoid, glikosida, tanin, polifenol, saponin, dan beberapa senyawa golongan alkaloid. Fraksi heksana merupakan fraksi non polar dimana dapat diduga mengandung senyawa asam lemak, steroid, dan terpenoid. Fraksi etil asetat termasuk fraksi semipolar dan dapat diduga memiliki kandungan senyawa yang terdiri dari golongan alkaloid dan flavonoid [16].

Besarnya hasil rendemen yang didapat disebabkan karena adanya perbedaan distribusi senyawa yang bergantung pada polaritas pelarut dimana sesuai prinsip like dissolve like bahwa senyawa akan saling tertarik berdasarkan kesaman sifat kepolarannya [16].

Pengujian aktivitas antibakteri ekstrak etanol daun kacapiring dan fraksinya menggunakan metode difusi cakram. Metode ini dipilih karena merupakan skrining awal untuk mengetahui aktivitas antibakteri suatu larutan uji. Selain itu, metode difusi cakram merupakan salah satu metode uji antibakteri yang relatif lebih sederhana, secara aplikasi lebih mudah dibanding metode uji lain,dan mudah dalam menyimpulkan hasil pengujian [17].

Berdasarkan hasil pengukuran diameter zona hambat seperti yang telah ditunjukkan pada tabel 1 sampel uji daun kacapiring memiliki aktivitas terhadap bakteri $S$. typhi pada fraksi etanol-air konsentrasi 30\%, dan $40 \%$ dengan diameter zona hambat masing-masing 7.564 $\pm 0,081$ dan $8.529 \pm 0,081 \mathrm{~mm}$.

Pada penelitian ini suspensi yang dibuat memiliki absorbansi 0,08. Artinya, absorbansi tersebut masih memasuki rentang dari standar yang ditetapkan. Namun, pembuatan suspensi bakteri tersebut tidak bisa dijadikan indikator utama dalam pengujian antibakteri karena rentang yang ditetapkan relatif besar sehingga dimungkinkan tidak memperhatikan faktor presisi dalam setiap pembuatan suspensi bakteri tetapi memperhatikan faktor rentang absorbansi. Akibatnya jumlah bakteri yang dihasilkan berbeda dalam setiap pengujiannya dan hasil aktivitas penghambatannya juga berbeda.

Hasil pengamatan juga menunjukkan bahwa beberapa sampel uji membentuk zona baru di sekitar area cakram seperti pada kelompok ekstrak, fraksi n-heksana, dan etil asetat sehingga zona bening tidak terlihat secara 
jelas di sekitar cakram. Kondisi ini dapat dipengaruhi oleh beberapa faktor, yaitu faktor pembuatan suspensi bakteri, dan faktor proses pemerataan bakteri pada media uji.

Berdasarkan hasil analisis statistik yang diperoleh sampel ekstrak, fraksi n-heksana, fraksi etil asetat pada semua konsentrasi dan fraksi etanol-air pada konsentrasi $20 \%$ dan $25 \%$ tidak memiliki perbedaan signifikan terhadap kelompok kontrol negatif $(p>0,05)$. Sedangkan pada sampel etanol-air konsentrasi $30 \%$ dan $40 \%$ menunjukkan perbedaan terhadap sampel konsentrasi $20 \%$ dan $25 \%$ dan kelompok kontrol negatif $(\mathrm{p}<0,05)$. Hasil analisis ini dapat disimpulkan bahwa sampel ekstrak, fraksi n-heksana, fraksi etil asetat semua konsentrasi dan fraksi etanol-air konsentrasi $20 \%$ dan $25 \%$ tidak memiliki aktivitas antibakteri karena tidak memiliki perbedaan signifikansi terhadap kelompok kontrol negatif. Sedangkan pada sampel fraksi etanol-air konsentrasi $30 \%$ dan $40 \%$ menunjukkan adanya perbedaan signifikan terhadap kelompok kontrol negatif sehingga dengan adanya perbedaan signifikansi menunjukkan adanya aktivitas antibakteri terhadap S.typhi. Namun, hasil statistik sampel fraksi etanol-air 30\% terhadap $40 \%$ tidak menunjukkan adanya perbedaan signifikan sehingga hasil tersebut dianggap memiliki nilai aktivitas penghambatan yang sama terhadap pertumbuhan S.typhi.

Adanya aktivitas antibakteri disebabkan oleh adanya senyawa metabolit sekunder pada daun kacapiring. AlFaruq dkk (2017) [18] dalam penelitiannya melaporkan bahwa daun Gardenia coronaria memiliki kandungan senyawa yang terdiri dari golongan alkaloid, glikosida, steroid, tannin, flavonoid, saponin, gums, dan golongan amida. pada penelitian lain juga dilaporkan bahwa daun kacapiring memiliki kandungan senyawa flavonoid, steroid, saponin, polifenol, dan alkaloid [19]. berdasarkan prinsip kemotaksonomi pada genus yang sama menunjukkan bahwa pada penelitian ini telah sesuai dengan hasil penelitian sebelumnya. adanya aktivitas antibakteri pada penelitian ini dapat diduga disebabkan karena adanya senyawa metabolit sekunder yang tekandung pada fraksi etanol-air atau senyawa polar. Adanya aktivitas antibakteri pada fraksi etanol-air konsentrasi $30 \%$ dan $40 \%$ disebabkan oleh adanya senyawa senyawa polar. Senyawa metabolit sekunder yang termasuk dalam senyawa polar terdiri dari golongan flavonoid, glikosida, polifenol, tanin, saponin, dan beberapa senyawa golongan alkaloid [16].

Daun kacapiring selain memiliki aktivitas antibakteri terhadap S.typhi juga memiliki aktivitas terhadap bakteri lain. Pada laporan beberapa penelitian lain dibuktikan bahwa daun kacapiring 50\% memiliki aktivitas antibakteri terhadap S.aureus $9,34 \mathrm{~mm}$ [20]. Nuralifah dkk (2019) [21] juga melaporkan aktivitas antibakteri daun kacapiring memiliki aktivitas antibakteri terhadap S.aureus dan Propionibacterium acnes masing-masing 9,75 dan 12 $\mathrm{mm}$ pada konsentrasi 15\%. Hasyim (2019) [18] melaporkan daun kacapiring $40 \%$ memiliki aktivitas antibakteri terhadap E.coli $9,45 \mathrm{~mm}$.
Mekanisme antibakteri dari flavonoid adalah efektif melawan mikroorganisme untuk membentuk kompleks dengan protein ekstraseluler dan dinding sel bakteri [22], saponin dapat berinteraksi dengan lipid A pada liposakarida bakteri gram negatif, sehingga mengganggu permeabilitas membrane sel bakteri [23], polifenol memiliki peranan menghambat enzim hidrolitik (protease dan karbohidrolase) atau interaksi lain yang dapat menonaktifkan adhesion serta non spesifik dengan karbohidrat. Alkaloid memiliki mekanisme antibakteri sebagai interkalator DNA dan menghambat enzim topoimerase [24]

\section{Kesimpulan}

Di antara sampel uji ekstrak, fraksi n-heksana, fraksi etil asetat, dan fraksi etanol-air yang memiliki aktivitas antibakteri tertinggi terdapat pada fraksi etanol-air yaitu pada konsentrasi $30 \%$ dan $40 \%$ berturut turut sebesar 7.564 dan $8.529 \mathrm{~mm}$. Namun diantara kedua konsentrasi tersebut tidak bisa ditentukan mana yang paling aktif karena secara statistik memiliki nilai aktivitas penghambatan yang hampir sama terhadap pertumbuhan bakteri S.typhi.

\section{Daftar Pustaka}

1. Dye, C. After 2015: Infectious Diseases In A New Era of Health and Development. Philosophical Transactions of the Royal Society B: Biological Sciences. 2015 ; 369(1645) ; 20130426.

2. Darmadi. Infeksi Nosokomial Problematika \& Pengendaliannya. Jakarta: Salemba Medika; 2008.

3. World Health Organization. 2018. WHO Typhoid.https://www.who.int/immunization/diseases/ typhoid/en/ [Diakses pada April.

4. Vaxcorp Indonesia. 2016. https://www.vaxcorpindo.com/typhoid-feverindonesia-favorite-disease/ [Diakses pada April 28, 2019].

5. Levine, M. M., M. B. Sztein, dan M. F. Pasett. The Immunological Basis for Immunization Series Module 20: Salmonella Enterica Serovar Typhi (Typhoid) Vaccines. 20. Geneva, Switzerland: Immunization, Vaccines and Biologicals. Word Health Organization. 2011.

6. Ivanova, Elena P.; Crawford, Russell J. (ed.). Antibacterial surfaces. Switzerland: Springer International Publishing, 2015.

7. Sandhori, F. Uji Aktivitas Antibakteri Terhadap Pseudomonas aeruginosa dan Staphylococcus aureus Dari Ekstrak Etanol Dan Faksi Rimpang Jahe Merah (Zingiber officinale Var. Rubrum). Skripsi. Jember.: Fakultas Framasi Universitas Jember; 2018.

8. Aberg, J. A., Lacy, C. F., Amstrong, L. L., Goldman, M. P., \& Lance, L. L. Drug Information Handbook. Lexi-Comp for the American Pharmacist Association. 2009

9. Mawan, A. R., S. E. Indriwati, dan Suhadi. Aktivitas 
Antibakteri Ekstrak Metanol Tumbuhan Salam (Syzygium polyanthum) Terhadap Pertumbuhan Bakteri Escherchia coli. Bioedukasi. 2017 ; 4(1):6468.

10. Chowdhury, A., S. Azam, M. A. Jainul, K. O. Faruq, dan A. Islam. Antibacterial Activities And In Vitro Anti-Inflammatory (Membrane Stability) Properties of Methanolic Extracts of Gardenia coronaria Leaves. International Journal of Microbiology. 2014 ; 2

11. Njinga, N. S., Sule, M. I., Pateh, U. U., Hassan, H. S., Usman, M. A., Bilkisu, A., \& Ache, R. N. Phytochemical and antimicrobial activity of the stembark of Gardenia aqualla Stapf Hutch (Rubeacea). Journal of Medicinal Plants Research, 2014, 8.27: 942-946.

12. Fang, S. L., Guan, J., Zhou, J. B., Xie, Y. Q., \& Meng, X. Studies on Antibacterial Activity of Gardenia Yellow Pigment. In: Proceedings of the 7th International Conference on Bioscience, Biochemistry and Bioinformatics. 2017 ; 50-55.

13. Vinay Kumar, N. M., Mahmood, R., Krishna, V., Ravishankar, B., \& Shastri, S. L. Evaluation of antibacterial activity from stem bark and leaf extracts of Gardenia gummifera Linn. Journal of Pharmacognosy and Phytochemistry. 2017; 6 (6): 2026-2030.

14. Rizkiana, L. Uji Aktivitas Antibakteri Ekstrak Etanol Dan Fraksi Daun Benalu (Scurrula Ferruginea (Jack.) Dans.) Apel Manalagi Terhadap Bakteri Staphylococcus aureus ATCC 6538 Dan Escherichia coli ATCC 25922. Skripsi. Jember: Fakultas Farmasi Universitas Jember. 2018.

15. Azis Saifudin, P. D. A. Senyawa Alam Metabolit Sekunder: Teori, Konsep, Dan Teknik Pemurnian. Yogyakarta: Budi Utama. 2014.

16. Sarker, S. D., Z. Latif, dan A. I. Gray. 2008. Natural Product Isolation. Edisi II. New Jersey, USA: Humana Pres

17. Reller, L. B., Weinstein, M., Jorgensen, J. H., \& Ferraro, M. J. Antimicrobial susceptibility testing: a review of general principles and contemporary practices. Clinical infectious diseases. 2009 ; 49(11), 1749-1755.

18. Al Faruq, A., Ibrahim, M., Chowdhury, M. M. U., Adib, M., Haque, M. R., \& Rashid, M. A. Pharmacological and Biological Activities of Different Fractions Methanol Extracts of Gardenia coronaria Buch.-Ham. Leaves. Bangladesh Pharmaceutical Journal. 2017 ; 20(2), 139-147.

19. Hasyim, Siti Nur Azizah. Skrining Fitokimia dan Uji Aktivitas AntibakterixEkstrak Etanol Daun Kaca Piring (Gardenia augusta Merr.) Terhadap Escherichia coli. Skripsi. Jember: Fakultas Farmasi Universitas Jember. 2019.

20. Seniarta, I. W. Uji Aktivitas Antibakteri Ekstrak Etanol dan Fraksi Daun Kaca Piring (Gardenia augusta Merr.) terhadap Staphylococcus aureus Skripsi. Jember: Fakultas Farmasi Universitas Jember. 2019.

21. Nuralifah, Fery Indradewi Armadani, Ni Nyoman Fitri Astari. Uji Aktivitas Antibakteri Ekstrak Etanol Daun Kacapiring (Gardenia jasminoides Ellis) Terhadap Bacteri Staphylococcus aureus dan Propionibacterium acnes. Medula. 2019 ; (6) 24430218

22. Mujeeb, Farina; Bajpai, Preeti; Pathak, Neelam. Phytochemical evaluation, antimicrobial activity, and determination of bioactive components from leaves of Aegle marmelos. BioMed research international, 2014.

23. Arabski, M., Wegierek-Ciuk, G. Czerwonka, A. Lankoff, dan W. Kaca. Effects of Saponins Againts Clinical Escherichia coli Strains and Eukaryotic. Journal of Biomedicine \& Biotechnology. 2012 ; 1-6

24. Karou, D., Dicko, M. H., Simpore, J., \& Traore, A. S. Antioxidant and antibacterial activities of polyphenols from ethnomedicinal plants of Burkina Faso. African journal of biotechnology. 2005; 4.8: 823-828. 